\title{
Impact of Nano-Chitosan Rate and Glutamine Acid Concentration on Growth, Yield and Volatile Oil Production of Coriander Plants
}

\author{
Nahed S. A. El Shayeb ${ }^{1 *}$, Reem H. I. Hassan ${ }^{1}$, Mohamed I. A. Mohaseb ${ }^{2}$ \\ ${ }^{1}$ Medicinal and Aromatic Department, Horticulture Research Institute, Agricultural Research Center, Egypt \\ ${ }^{2}$ Soil, Water and Evironment Research Institute, Agricultural Research Center, Egypt \\ Email: nahed_elshyeb@hotmail.com
}

Received: 15 June 2020; Revised: 10 August 2020; Accepted: 10 August 2020

\begin{abstract}
Coriander (Coriandrum sativum, L.) is an important aromatic plant in Egypt. A current work was aimed to study the impact of nano-chitosan rates $(0.0,2$ and $4 \mathrm{ml} / 1)$, glutamine acid concentrations $(0.0,25,50$ and $100 \mathrm{ppm})$ and their interaction treatments on growth, yield components as well as volatile oil and some chemical constituents of coriander plant. Two field experiments were conducted at Kafr El-Hamam Experimental Station of Agric. Res. Cen., ElSharkia Governorate, Egypt during 2018/2019 and 2019/2020 seasons. This experiments were based as a splitplot in randomized block design with three replications. The nano-chitosan rates were randomly arranged in the main plots, while, glutamine acid (Gln) concentrations were distributed randomly in the sub plots. Based on two years study it was found that most of nano-chitosan rates and glutamine acid concentrations proved to be superior and recorded higher values of coriander yield components over control. Application of nano-chitosan at $4 \mathrm{ml} / 1$ resulted higher values of coriander growth (plant height, branch number per plant and total dry weight), yield components (number of inflorescences per coriander plant, fruit yield per plant and per feddan), volatile oil production (volatile oil percentage, volatile oil yield per plant and per feddan) as well as chemical constituents (N, P, K and total carbohydrates percentages in fruits and total chlorophyll content in coriander leaves) over the lowest rate and control. The same trend in these characters of coriander was obtained when Gln acid was used as foliar spray at $100 \mathrm{ppm}$ concentration compared to the other ones under study. In general, nano-chitosan at $4 \mathrm{ml} / 1$ interacted with Gln acid at $50 \mathrm{ppm}$ recorded the highest values of yield components of coriander plants compared to the other interaction treatments under study. Finally, this treatment gave the highest values in major constituents of volatile oil such as linalool, camphor, gamma-terpinene, geranyl acetate and alpha-pinene.
\end{abstract}

Keywords: coriander, nano-chitosan, glutamine, growth, yield, chlorophyll, NPK

\section{Introduction}

Coriander (Coriandrum sativum L., Apiaceous plant) is a valuable aromatic plant with a high consumption in the Mediterranean region, including Egypt. The fruits are popular as a condiment and the finely ground fruit is a large ingredient of curry powder. It contains volatile oil and linalool component is the major one [1]. Coriander is economically substantial since it has been utilized as a flavoring laborer in cosmetics, food products and perfumes. Coriander products are used medically as a drug for against worms, indigestion, pain in joints and rheumatism [2].

Copyright (C2020 Nahed S. A. El Shayeb, et al.

DOI: https://doi.org/10.37256/jba.112021486

This is an open-access article distributed under a CC BY license

(Creative Commons Attribution 4.0 International License)

https://creativecommons.org/licenses/by/4.0/ 
Nano-chitosan gained and remarkable position due to their peerless physical and chemical feature, including length, diameter, atomic arrangements and operation, which allow them to have tension strength, wide-ranging conductivity, elasticity and chemical reactivity characteristics [3]. Where plants applied with low concentrations of nano-chitosan can have positive influenced on plant development, yield raising and water transport within the plant, or no evidence of phytotoxicity; contrary to the negative influences that can be produced by high dosage tested; as they breed harmful reactionary oxygen species [4]. Moreover, Hasaneen et al. [5] reported that low dose of nano-fertilizers (chitosanNPK) have seen to be beneficial, enhancing water absorption and uptake of nutrients, found to enhance the French bean growth and yield.

Amino acids is a well recognized biostimulant which has positive influences on several plants especially regard growth parameters, yield and significantly alleviates the injuries caused by different stresses [6]. Clearly, the glutamate absorbs by the cells faster than it is metabolized, as the glutamate finally is set in glutamine acid (Gln), protein and glutathione [7]. Glutamine as well is a pivotal amino acid in plant physiology with key functions in numerous metabolic procedures, including nitrogen intake pathways [8-9]. Furthermore, shoot length, bulb diameter, number of leaves and fresh and dry weight of onion plant at full vegetative stage were increased by using amino acids as foliar spray [10].

Therefore, in this study the enhancement effects of nano-chitosan rates and glutamine in different concentrations, via foliar application, were recorded on the growth, fruit yields, volatile oil production and some chemical constituents of coriander (Coriandrum sativum, L.) plants.

\section{Materials and methods}

Nano-chitosan was applied as foliar application with the rates of 0.0, 2.0 and $4.0 \mathrm{ml} / \mathrm{l}$. Different glutamine acid (Gln) concentrations of 0.0, 25, 50 and 100 ppm were tested. The treatments were arranged in a split-plot in randomized complete blocks design with three replicates. Nano-chitosan rates were randomly arranged in the main plots and Gln acid were randomly distributed in the sub plots. Two field experiments were conducted during two consecutive cropping seasons 2018/2019 and 2019/2020 at Kafr El-Hamam Experimental Station of Agric. Res. Cen., ElSharkia Governorate, Egypt, to study the impact of main factors effect and their interactions on growth, yield, volatile oil as well as some chemical constituents of coriander plants. Soil physical and chemical characteristics of the experimental area are (average of the two seasons) presented in Table 1.

Table 1. Physical and chemical properties of experimental soil (average of the two seasons)

\begin{tabular}{|c|c|c|c|c|c|c|c|c|c|c|c|c|}
\hline & \multicolumn{9}{|c|}{ Physical analysis } & \multicolumn{3}{|c|}{ Soil texture } \\
\hline & $\frac{\text { Clay }(\%)}{42.5}$ & $\frac{\text { Silt }(\%)}{38.6}$ & \multicolumn{4}{|c|}{13.4} & \multicolumn{3}{|c|}{5.5} & \multicolumn{3}{|c|}{ Clayey } \\
\hline \multicolumn{13}{|c|}{ Chemical analysis } \\
\hline $\mathrm{pH}$ & E.C. m.mohs $/ \mathrm{cm}$ & Organic mater $(\%)$ & \multicolumn{4}{|c|}{ Soluble cations (meq./L) } & \multicolumn{3}{|c|}{ Soluble anions (meq./L) } & \multicolumn{3}{|c|}{ Available (ppm) } \\
\hline 7.85 & 1.2 & 0.32 & 2.6 & 3.2 & 5.3 & 0.9 & 8.2 & 2.1 & 1.7 & 82 & 6 & 218 \\
\hline
\end{tabular}

Fruits of coriander (cv., Gizal) were obtained from Agriculture Research Centre (ARC), Dokky, Giza. Coriander fruits were sowing on 17 th October of both seasons. Fruits were sown at space of $30 \mathrm{~cm}$ in two sides. After three weeks from sowing, germinated plants were thinned to two plants/hill. Experimental plot was $14.40 \mathrm{~m}^{2}(4 \times 3.60 \mathrm{~m})$ included 6 rows; each row was $60 \mathrm{~cm}$ apart and $4 \mathrm{~m}$ in length. Nano-chitosan rates and glutamine acid concentrations were added as foliar application. The first application began after 30 days after planting and repeated every 15 days until the end of the season.

All coriander plants were fertilized with potassium and phosphorus fertilization at the rate of $50 \mathrm{~kg} / \mathrm{fed}$., of potassium sulphate $\left(48 \% \mathrm{~K}_{2} \mathrm{O}\right)$ and $200 \mathrm{~kg} / \mathrm{fed}$., of calcium super phosphate $\left(15.5 \% \mathrm{P}_{2} \mathrm{O}_{5}\right)$ and added during soil 
preparation as a soil dressing application. Nitrogen fertilizer as ammonium sulphate $(20.5 \% \mathrm{~N})$ at $150 \mathrm{~kg} / \mathrm{fed}$., was divided into three equal portions and was added to the soil after 30, 45 and 60 days from sowing. All coriander plants received normal agricultural practices whenever they needed.

\subsection{Data recorded}

Growth characters: Coriander plant height $(\mathrm{cm})$, number of branches/plant and total dry weight/plant $(\mathrm{g})$ from 9 plants of coriander were recorded at 70 days after sowing.

Yield Components: Number of umbels/plant, fruit yield/plant $(\mathrm{g})$ and/feddan $(\mathrm{kg})$ coriander plant were determined at harvest time.

Volatile oil production: Volatile oil percentage in coriander fruits were determined according to [11] then volatile oil yield/coriander plant $(\mathrm{ml})$ and/feddan (l) were calculated.

Active constituents in coriander volatile oil: GLC (Gas Liquid Chromatography) (Hewlett, Packed, HP6890 series) analysis of the coriander volatile oil from the samples (second season) was used to determine volatile oil constituents for the obtained oil from the best treatments of nano-chitosan rate and glutamine acid concentration as well as their interactions.

Chemical Constituents: Total nitrogen, total phosphorus and potassium percentages in coriander fruits were determined according to [12]. Total carbohydrate percentage in coriander fruits was determined according to the method described by [13]. Also, total chlorophyll content (SPAD unit) was determined in coriander fresh leaves by using SPAD502 meter as reported by [14].

Statistical Analysis: The statistical layout of this experiment was a split-plot in a randomized complete block design. Where, nano-chitosan rates were randomly distributed in the main plots, while glutamine acid concentrations were randomly arranged in sub-plots. Each treatment was included three replicates. Data were analyzed according to [15]. Least significance difference (LSD) was used to differentiate means at the at $5 \%$ level of probability. The means were compared using computer program of Statistix version 9 [16].

\section{Results and discussion}

\subsection{Plant growth characters}

Data listed in Table 2 suggest that coriander plant height $(\mathrm{cm})$, branch numbers per plant and total dry weight per plant (g) significantly increased with most of nano-chitosan rates compared to control. Furthermore, nano-chitosan at $4 \mathrm{ml} / \mathrm{l}$ recorded higher increases in coriander growth characters compared with the other rate $(2 \mathrm{ml} / \mathrm{l})$ under study and control during the two seasons. However, a positive influence of chitosan has been noticed on the growth of roots, shoots and leaves of various plants including gerbera [17]. In addition, chitosan has a significant influence on the development and growth of various plants like coffee [18], Dendrobium formossum [19], wheat [20] and strawberry [21].

Results tabulated in Table 2 show that plant height, number of branches per coriander plant as well as total dry weight per plant were gradually increased with increasing glutamine acid concentrations in both seasons. In addition, the highest rate of Gln. acid gave highest values in this connection with significant differences between other ones under study, in most cases. It is well known that the tested glutamine acid supply the plant with the required necessary for the growth and development. El-Zohiri and Asfour [22] on potato revealed that spraying of amino acids at 0.25 $\mathrm{ml} / \mathrm{l}$ significantly increased vegetative growth expressed as plant height and dry weight of plant. Glutamine showed superiority over other plant growth regulators regarding Hibiscus moscheutos growth especially shoot length [23].

Table 2 illustrate that, generally, interaction between nano-chitosan rates and glutamine acid concentrations significantly increased plant height, branch number/plant and total dry weight/coriander plant compared to the control in both seasons. Furthermore, the best interaction treatment in this concern was that of nano-chitosan at $4 \mathrm{ml} / 1$ interacted with glutamine concentration at $100 \mathrm{ppm}$. Also, all interaction treatments were higher than individual nano-chitosan rates or individual glutamine acid concentrations. Moreover, as mentioned above, both nano-chitosan rates and glutamine acid concentrations (each alone) increased coriander growth characters, in turn; they together might maximize their effects leading to taller, more branches and heaviest dry weight. These results are in line with those reported by 
[24] who indicated that Cu-chitosan nano-particles improved growth, seed germination, seedling length, fresh and dry weight of tomato at $0.08,0.10$ and $0.12 \%$ levels. Also, Zayed et al. [25] who reported that the best treatment on bean plant growth variables (plant height, leaf area, fresh and dry weights of the shoot and root) was nano-chitosan (0.3\%) compared to control. Furthermore, Spraying bean plants by Glutamine at 25 or 50 ppm increased vegetative growth (number of branches as well as dry weight of whole plant) [26].

Table 2. Effect on nano-chitosan rate $(\mathrm{N})$, glutamine concentration $(\mathrm{G})$ and their interaction $(\mathrm{N} \times \mathrm{G})$ treatments on vegetative growth characters of coriander (Coriandrum sativum) plant during the two seasons

\begin{tabular}{|c|c|c|c|c|c|c|c|c|c|c|}
\hline \multirow{3}{*}{$\begin{array}{c}\text { Nano-chitosan rate } \\
(\mathrm{ml} / \mathrm{l})\end{array}$} & \multicolumn{10}{|c|}{ Glutamine acid concentration (ppm) } \\
\hline & 0.0 & 25 & 50 & 100 & Mean $(\mathrm{N})$ & 0.0 & 25 & 50 & 100 & Mean $(\mathrm{N})$ \\
\hline & \multicolumn{6}{|c|}{ 2018/2019 season } & \multicolumn{3}{|c|}{ 2019/2020 season } & \\
\hline & \multicolumn{10}{|c|}{ Plant height $(\mathrm{cm})$} \\
\hline 0.0 & 64.89 & 66.00 & 65.44 & 71.55 & 66.97 & 68.22 & 70.44 & 74.00 & 77.78 & 72.61 \\
\hline 2.0 & 65.67 & 67.00 & 68.44 & 69.89 & 67.75 & 70.00 & 71.22 & 75.44 & 80.11 & 74.20 \\
\hline 4.0 & 70.11 & 71.78 & 72.66 & 79.44 & 73.50 & 71.00 & 78.00 & 79.66 & 80.89 & 77.39 \\
\hline Mean (G) & 66.89 & 68.26 & 68.85 & 73.63 & & 69.74 & 73.22 & 76.37 & 77.39 & \\
\hline \multirow[t]{2}{*}{ LSD at $5 \%$} & $(\mathrm{~N})=0.73$ & \multicolumn{2}{|c|}{$(\mathrm{G})=1.10$} & \multicolumn{2}{|c|}{$(\mathrm{N} \times \mathrm{G})=1.80$} & $(\mathrm{~N})=0.41$ & \multicolumn{2}{|c|}{$(G)=1.04$} & \multicolumn{2}{|c|}{$(\mathrm{N} \times \mathrm{G})=1.61$} \\
\hline & \multicolumn{10}{|c|}{ Number of branches/plant } \\
\hline 0.0 & 5.55 & 7.55 & 7.78 & 9.11 & 7.50 & 6.78 & 8.11 & 8.44 & 10.00 & 8.33 \\
\hline 2.0 & 7.89 & 9.44 & 10.78 & 12.67 & 10.19 & 9.00 & 11.11 & 12.67 & 13.78 & 11.64 \\
\hline 4.0 & 9.34 & 12.22 & 12.89 & 13.11 & 11.89 & 10.89 & 12.11 & 13.11 & 15.55 & 12.92 \\
\hline Mean (G) & 7.59 & 9.74 & 10.48 & 11.63 & & 8.89 & 10.44 & 11.41 & 13.11 & \\
\hline \multirow[t]{2}{*}{ LSD at $5 \%$} & $(N)=0.65$ & \multicolumn{2}{|c|}{$(G)=0.55$} & \multicolumn{2}{|c|}{$(\mathrm{N} \times \mathrm{G})=1.04$} & $(\mathrm{~N})=0.57$ & \multicolumn{2}{|c|}{$(G)=0.44$} & \multicolumn{2}{|c|}{$(\mathrm{N} \times \mathrm{G})=0.86$} \\
\hline & \multicolumn{10}{|c|}{ Total dry herb weight/plant (g) } \\
\hline 0.0 & 14.46 & 17.32 & 18.24 & 18.65 & 17.17 & 16.00 & 18.25 & 19.17 & 20.37 & 18.45 \\
\hline 2.0 & 18.93 & 20.00 & 22.09 & 24.48 & 21.38 & 20.37 & 23.06 & 25.82 & 27.96 & 24.45 \\
\hline 4.0 & 19.61 & 21.79 & 26.21 & 27.10 & 23.68 & 23.93 & 26.06 & 29.00 & 28.83 & 26.96 \\
\hline Mean (G) & 17.67 & 19.71 & 22.18 & 23.40 & & 20.29 & 22.46 & 24.67 & 25.72 & \\
\hline LSD at $5 \%$ & $(\mathrm{~N})=0.82$ & (G & $=0.74$ & $(\mathrm{~N} \times$ & i) $=1.37$ & $(\mathrm{~N})=0.59$ & & 0.53 & $(\mathrm{~N} \times$ & i) $=0.98$ \\
\hline
\end{tabular}

\subsection{Fruit yield components and volatile oil production}

There were significant differences in number of umbels per coriander plant, fruit yield per plant (g) and fruit yield per feddan $(\mathrm{kg})$ as coriander yield components (Table 3) as well as volatile oil percentage, volatile oil yield per plant $(\mathrm{ml})$ and volatile oil yield per feddan (1) as volatile oil production characters (Table 4) under the effect of all the tested nano-chitosan rates. Furthermore, these yield component and volatile oil production characters were increased gradually by increasing the used nano-chitosan rates. The highest level of nano-chitosan $(4 \mathrm{ml} / \mathrm{l})$ ) gave significant increases in this regard compared to control in both seasons. Abdel-Aziz et al. [5] on wheat plant reported similar results as affected by nano chitosan-NPK fertilizer application as compared with control yield variables of plants treated with normal fertilized NPK. 
Table 3. Effect on nano-chitosan rate $(\mathrm{N})$, glutamine concentration $(\mathrm{G})$ and their interaction $(\mathrm{N} \times \mathrm{G})$ treatments on yield component characters of coriander (Coriandrum sativum) plant during the two seasons

\begin{tabular}{|c|c|c|c|c|c|c|c|c|c|c|}
\hline \multirow{3}{*}{$\begin{array}{l}\text { Nano-chitosan rate } \\
(\mathrm{ml} / \mathrm{l})\end{array}$} & \multicolumn{10}{|c|}{ Glutamine concentration (ppm) } \\
\hline & 0.0 & 25 & 50 & 100 & Mean $(\mathrm{N})$ & 0.0 & 25 & 50 & 100 & Mean $(\mathrm{N})$ \\
\hline & \multicolumn{6}{|c|}{ 2018/2019 season } & \multicolumn{3}{|c|}{ 2019/2020 season } & \\
\hline & \multicolumn{10}{|c|}{ Number of umbels/plant } \\
\hline 0.0 & 14.11 & 16.00 & 17.00 & 18.11 & 16.30 & 16.00 & 17.89 & 19.78 & 21.78 & 18.86 \\
\hline 2.0 & 16.78 & 19.33 & 19.55 & 23.34 & 19.75 & 17.66 & 20.11 & 27.11 & 27.11 & 23.00 \\
\hline 4.0 & 20.89 & 23.78 & 26.44 & 26.78 & 24.47 & 22.89 & 27.44 & 29.78 & 29.00 & 27.28 \\
\hline Mean (G) & 17.26 & 19.70 & 21.00 & 22.74 & & 18.85 & 21.81 & 25.55 & 25.96 & \\
\hline \multirow[t]{2}{*}{ LSD at $5 \%$} & $(\mathrm{~N})=1.91$ & \multicolumn{2}{|c|}{$(\mathrm{G})=1.61$} & \multicolumn{2}{|c|}{$(\mathrm{N} \times \mathrm{G})=3.05$} & $(N)=1.60$ & \multicolumn{2}{|c|}{$(G)=0.58$} & \multicolumn{2}{|c|}{$(\mathrm{N} \times \mathrm{G})=1.81$} \\
\hline & \multicolumn{10}{|c|}{ Fruit yield/plant (g) } \\
\hline 0.0 & 5.22 & 5.85 & 6.64 & 6.97 & 6.17 & 5.74 & 6.29 & 7.45 & 8.10 & 6.90 \\
\hline 2.0 & 6.06 & 7.51 & 10.26 & 10.61 & 8.61 & 7.02 & 7.61 & 11.02 & 11.43 & 9.27 \\
\hline 4.0 & 8.15 & 10.70 & 12.38 & 11.65 & 10.72 & 8.79 & 12.46 & 12.92 & 12.81 & 11.75 \\
\hline Mean (G) & 6.48 & 8.02 & 9.76 & 9.74 & & 7.19 & 8.79 & 10.46 & 10.78 & \\
\hline \multirow[t]{2}{*}{ LSD at $5 \%$} & $(\mathrm{~N})=0.24$ & \multicolumn{2}{|c|}{$(G)=0.38$} & \multicolumn{2}{|c|}{$(\mathrm{N} \times \mathrm{G})=0.62$} & $(N)=0.62$ & \multicolumn{2}{|c|}{$(G)=0.23$} & \multicolumn{2}{|c|}{$(\mathrm{N} \times \mathrm{G})=0.98$} \\
\hline & \multicolumn{10}{|c|}{ Fruit yield/feddan (kg) } \\
\hline 0.0 & 487.5 & 545.7 & 619.7 & 650.5 & 575.9 & 536.0 & 587.1 & 695.7 & 755.7 & 643.6 \\
\hline 2.0 & 565.9 & 701.3 & 957.3 & 990.6 & 803.8 & 655.5 & 710.0 & 1028.5 & 1066.8 & 865.2 \\
\hline 4.0 & 761.0 & 998.7 & 1155.5 & 1087.0 & 1000.5 & 820.7 & 1162.9 & 1205.9 & 1195.9 & 1096.4 \\
\hline Mean (G) & 604.8 & 748.5 & 910.8 & 909.4 & & 670.8 & 820.0 & 976.7 & 1006.1 & \\
\hline LSD at $5 \%$ & $(\mathrm{~N})=22.5$ & (G & $=35.5$ & $(\mathrm{~N} \times$ & $=57.6$ & $(\mathrm{~N})=86.3$ & $(\mathrm{G}$ & 21.9 & $(\mathrm{~N} \times$ & $=91.8$ \\
\hline
\end{tabular}

Results in Table 3 and 4 show that, there was an increase in fruit and volatile oil yields per coriander plant and per feddan with increasing the tested glutamine concentrations during the two seasons. However, there was significant differences between all concentrations of glutamine acid especially treatment of $100 \mathrm{ppm}$, which gave significant increases compared to the other ones under study and control. Yunsheng et al. [26] stated that spraying bean plants by Glutamine ( $25 \mathrm{ppm}, 50 \mathrm{ppm})$ increased total yield and its quality with no significant difference between them.

Recorded data in Tables 3 and 4 indicate that, in most cases, under the two tested nano-chitosan rates (2.0 and 4.0 $\mathrm{ml} / \mathrm{l}$ ) different concentrations of glutamine acid gave significant increases in of coriander yield components (number of umbels per coriander plant, fruit yield per plant and fruit yield per feddan) and volatile oil production (volatile oil percentage, volatile oil yield per plant and volatile oil yield per feddan) as compared to control during both seasons. Moreover, interaction of nano-chitosan at $4.0 \mathrm{ml} / 1$ with 50 or $100 \mathrm{ppm}$ glutamine acid gave the highest fruit yield component values with no significant between them, in most cases. Moreover, Behboudi et al. [27] found that using the chitosan nano particles, especially 60 and $90 \mathrm{ppm}$ increased the number of grain per spike, the barley grain yield and the harvest index compared to the control. Also, Saeed et al. [28] on soybean found that treatments of amino acids significantly improved growth parameters of pod yield. 
Table 4. Effect on nano-chitosan rate $(\mathrm{N})$, glutamine concentration $(\mathrm{G})$ and their interaction $(\mathrm{N} \times \mathrm{G})$ treatments on volatile oil production characters of coriander (Coriandrum sativum) plant during the two seasons

\begin{tabular}{|c|c|c|c|c|c|c|c|c|c|c|}
\hline \multirow{3}{*}{$\underset{(\mathrm{ml} / \mathrm{l})}{\text { Nano-chitosan rate }}$} & \multicolumn{10}{|c|}{ Glutamine concentration (ppm) } \\
\hline & 0.0 & 25 & 50 & 100 & Mean $(\mathrm{N})$ & 0.0 & 25 & 50 & 100 & Mean (N) \\
\hline & \multicolumn{6}{|c|}{ 2018/2019 season } & \multicolumn{3}{|c|}{ 2019/2020 season } & \\
\hline & \multicolumn{10}{|c|}{ Volatile oil (\%) } \\
\hline 0.0 & 0.266 & 0.266 & 0.302 & 0.357 & 0.298 & 0.280 & 0.290 & 0.333 & 0.351 & 0.314 \\
\hline 2.0 & 0.269 & 0.311 & 0.368 & 0.381 & 0.332 & 0.294 & 0.339 & 0.392 & 0.397 & 0.356 \\
\hline 4.0 & 0.288 & 0.307 & 0.326 & 0.345 & 0.317 & 0.319 & 0.390 & 0.437 & 0.424 & 0.393 \\
\hline Mean $(\mathrm{G})$ & 0.274 & 0.295 & 0.332 & 0.361 & & 0.298 & 0.340 & 0.387 & 0.391 & \\
\hline \multirow[t]{2}{*}{ LSD at $5 \%$} & $(N)=0.029$ & \multicolumn{2}{|c|}{$(G)=0.023$} & \multicolumn{2}{|c|}{$(\mathrm{N} \times \mathrm{G})=0.044$} & $(\mathrm{~N})=0.020$ & \multicolumn{2}{|c|}{$(G)=0.016$} & \multicolumn{2}{|c|}{$(\mathrm{N} \times \mathrm{G})=0.031$} \\
\hline & \multicolumn{10}{|c|}{ Volatile oil yield/plant (ml) } \\
\hline 0.0 & 0.014 & 0.016 & 0.020 & 0.025 & 0.019 & 0.016 & 0.018 & 0.025 & 0.029 & 0.022 \\
\hline 2.0 & 0.017 & 0.024 & 0.038 & 0.040 & 0.030 & 0.021 & 0.026 & 0.043 & 0.045 & 0.034 \\
\hline 4.0 & 0.024 & 0.033 & 0.040 & 0.040 & 0.034 & 0.028 & 0.049 & 0.053 & 0.056 & 0.046 \\
\hline Mean (G) & 0.018 & 0.024 & 0.033 & 0.035 & & 0.022 & 0.031 & 0.040 & 0.043 & \\
\hline \multirow[t]{2}{*}{ LSD at $5 \%$} & $(N)=0.003$ & \multicolumn{2}{|c|}{$(G)=0.003$} & \multicolumn{2}{|c|}{$(\mathrm{N} \times \mathrm{G})=0.005$} & $(\mathrm{~N})=0.005$ & \multicolumn{2}{|c|}{$(G)=0.002$} & \multicolumn{2}{|c|}{$(\mathrm{N} \times \mathrm{G})=0.006$} \\
\hline & \multicolumn{10}{|c|}{ Volatile oil yield/feddan (1) } \\
\hline 0.0 & 1.30 & 1.45 & 1.87 & 2.32 & 1.74 & 1.50 & 1.70 & 2.32 & 2.65 & 2.04 \\
\hline 2.0 & 1.52 & 2.19 & 3.52 & 3.77 & 2.75 & 1.93 & 2.43 & 4.04 & 4.23 & 3.15 \\
\hline 4.0 & 2.19 & 3.07 & 3.77 & 3.77 & 3.20 & 2.62 & 4.54 & 4.91 & 5.23 & 4.32 \\
\hline Mean (G) & 1.67 & 2.24 & 3.05 & 3.29 & & 2.02 & 2.89 & 3.75 & 4.04 & \\
\hline LSD at $5 \%$ & $(\mathrm{~N})=0.29$ & \multicolumn{2}{|c|}{$(G)=0.27$} & \multicolumn{2}{|c|}{$(\mathrm{N} \times \mathrm{G})=0.49$} & $(\mathrm{~N})=0.44$ & \multicolumn{2}{|c|}{$(G)=0.18$} & \multicolumn{2}{|c|}{$(\mathrm{N} \times \mathrm{G})=0.51$} \\
\hline
\end{tabular}

\subsection{Major active constitutes of coriander volatile oil}

The obtained results by Gas liquid chromatographic analysis in Table 5 pointed out that interaction between nanochitosan at $4 \mathrm{ml} / \mathrm{l}$ with foliar spray of glutamine at 50 or $100 \mathrm{ppm}$ gave the highest values of main active constitutes of coriander volatile oil (linalool, camphor, gamma-terpinene, geranyl acetate and alpha-pinene) compared to control or other ones. While the highest values of P-cymene was obtained from $100 \mathrm{ppm}$ of glutamine alone compared to the other ones.

Table 5. Effect of best nano-chitosan rates, glutamine concentrations and their interaction treatments on major active constitutes of coriander (Coriandrum sativum) plant during the second season

\begin{tabular}{|c|c|c|c|c|c|}
\hline \multirow{2}{*}{$\begin{array}{c}\text { Major components of coriander } \\
\text { volatile oil }(\%)\end{array}$} & \multicolumn{5}{|c|}{ Treatments } \\
\hline & Control & $\begin{array}{c}\text { Nano-chitosan at } 4 \\
\mathrm{ml} / 1\end{array}$ & $\begin{array}{l}\text { Glutamine at } 100 \\
\text { ppm }\end{array}$ & $\begin{array}{l}4 \mathrm{ml} / 1 \text { nano-chitosan } \\
+50 \mathrm{ppm} \text { glutamine }\end{array}$ & $\begin{array}{l}4 \mathrm{ml} / 1 \text { nano-chitosan } \\
+100 \text { ppm glutamine }\end{array}$ \\
\hline Linalool & 76.52 & 78.72 & 78.36 & 80.76 & 81.41 \\
\hline Camphor & 2.07 & 1.96 & 1.98 & 2.18 & 2.64 \\
\hline Gamma-terpinene & 2.01 & 2.25 & 2.30 & 2.29 & 2.34 \\
\hline P-cymene & 1.01 & 1.02 & 1.13 & 1.09 & 1.06 \\
\hline Geranyl acetate & 1.87 & 1.82 & 1.66 & 1.93 & 1.88 \\
\hline Geraniol & 3.25 & 3.16 & 2.89 & 3.31 & 2.97 \\
\hline Alpha-pinene & 1.63 & 1.59 & 1.72 & 1.76 & 1.80 \\
\hline
\end{tabular}




\subsection{Chemical constituents}

Data in Tables 6 and 7 reveal that percentages of total nitrogen, total phosphorus, potassium and total carbohydrates in coriander fruits as well as total chlorophyll content (SPAD unit) in coriander leaves were increased by increasing nano-chitosan rates. Likewise, the two nano-chitosan rates gave significant increases in this respect compared to control during the two seasons. Also, the highest values in this concern were achieved by the nano-chitosan rate of $4 \mathrm{ml} / 1$ compared to control in the two seasons. These resulted are in agreed with those reported by [29] who found that nanochitosan have shown to effect the biophysical parameters of coffee seedlings by increasing pigment content and the rate of photosynthesis as well as nutrient uptake. Also, chitosan had the ability to enhance chlorophyll content and nutrient uptake of plants [18]. However, the response of plants to nanofertilizers varies with the type of crop species, their nature of nanomaterials and growth stages [30].

The obtained results in Tables 6 and 7 demonstrate that increasing rates of glutamine acid concentrations gradually increased total nitrogen, total phosphorus, potassium and total carbohydrates percentages in coriander fruits as well as total chlorophyll content (SPAD unit) in coriander leaves. In addition, all treatments gave significant differences compared to control, in most cases. Moreover, the highest concentration of glutamine acid (100 ppm) recorded the highest values in this connection. However, tissue culture supplementing basal media with glutamine enables higher nitrogen intake due to an improve of both assimilation ability and nitrogen sources [31]. In addition, Noroozlo et al. [32] found that foliar application of glycine and glutamine amino acids can have beneficial effects on lettuce leaf chlorophyll content and vitamin $\mathrm{C}$ were obtained by low to moderate concentrations of glutamine amino acid.

Table 6. Effect on nano-chitosan rate $(\mathrm{N})$, glutamine concentration $(\mathrm{G})$ and their interaction $(\mathrm{N} \times \mathrm{G})$ treatments on total nitrogen, total phosphorus and potassium percentages of coriander (Coriandrum sativum) plant during the two seasons

\begin{tabular}{|c|c|c|c|c|c|c|c|c|c|c|}
\hline \multirow{3}{*}{$\begin{array}{l}\text { Nano-chitosan rate } \\
(\mathrm{ml} / \mathrm{l})\end{array}$} & \multicolumn{10}{|c|}{ Glutamine concentration (ppm) } \\
\hline & 0.0 & 25 & 50 & 100 & $\operatorname{Mean}(\mathrm{N})$ & 0.0 & 25 & 50 & 100 & Mean $(\mathrm{N})$ \\
\hline & \multicolumn{6}{|c|}{$2018 / 2019$ season } & \multicolumn{3}{|c|}{$2019 / 2020$ season } & \\
\hline & \multicolumn{10}{|c|}{ Total nitrogen $(\%)$ in fruits } \\
\hline 0.0 & 2.127 & 2.147 & 2.220 & 2.307 & 2.200 & 2.183 & 2.223 & 2.270 & 2.353 & 2.258 \\
\hline 2.0 & 2.170 & 2.210 & 2.270 & 2.300 & 2.238 & 2.197 & 2.247 & 2.330 & 2.353 & 2.282 \\
\hline 4.0 & 2.197 & 2.247 & 2.320 & 2.343 & 2.277 & 2.267 & 2.313 & 2.377 & 2.380 & 2.334 \\
\hline Mean (G) & 2.164 & 2.201 & 2.270 & 2.317 & & 2.216 & 2.261 & 2.326 & 2.362 & \\
\hline \multirow[t]{2}{*}{ LSD at $5 \%$} & $(\mathrm{~N})=0.005$ & \multicolumn{2}{|c|}{$(G)=0.010$} & \multicolumn{2}{|c|}{$(\mathrm{N} \times \mathrm{G})=0.016$} & $(\mathrm{~N})=0.012$ & \multicolumn{2}{|c|}{$(G)=0.015$} & \multicolumn{2}{|c|}{$(\mathrm{N} \times \mathrm{G})=0.025$} \\
\hline & \multicolumn{10}{|c|}{ Total phosphorus $(\%)$ in fruits } \\
\hline 0.0 & 0.279 & 0.327 & 0.376 & 0.376 & 0.339 & 0.293 & 0.356 & 0.385 & 0.390 & 0.356 \\
\hline 2.0 & 0.359 & 0.387 & 0.404 & 0.405 & 0.389 & 0.340 & 0.382 & 0.424 & 0.426 & 0.393 \\
\hline 4.0 & 0.381 & 0.403 & 0.446 & 0.443 & 0.418 & 0.369 & 0.398 & 0.452 & 0.441 & 0.415 \\
\hline Mean (G) & 0.340 & 0.372 & 0.409 & 0.408 & & 0.334 & 0.378 & 0.420 & 0.419 & \\
\hline \multirow[t]{2}{*}{ LSD at $5 \%$} & $(\mathrm{~N})=0.011$ & \multicolumn{2}{|c|}{$(G)=0.008$} & \multicolumn{2}{|c|}{$(\mathrm{N} \times \mathrm{G})=0.016$} & $(\mathrm{~N})=0.010$ & \multicolumn{2}{|c|}{$(G)=0.007$} & \multicolumn{2}{|c|}{$(\mathrm{N} \times \mathrm{G})=0.015$} \\
\hline & \multicolumn{10}{|c|}{ Potassium (\%) in fruits } \\
\hline 0.0 & 2.737 & 2.877 & 2.987 & 3.187 & 2.947 & 2.813 & 2.930 & 3.097 & 3.140 & 2.995 \\
\hline 2.0 & 2.780 & 3.193 & 3.377 & 3.507 & 3.214 & 3.100 & 3.277 & 3.480 & 3.647 & 3.376 \\
\hline 4.0 & 3.300 & 3.377 & 3.520 & 3.567 & 3.441 & 3.223 & 3.513 & 3.697 & 3.693 & 3.532 \\
\hline $\operatorname{Mean}(\mathrm{G})$ & 2.939 & 3.149 & 3.294 & 3.420 & & 3.046 & 3.240 & 3.424 & 3.493 & \\
\hline LSD at $5 \%$ & $(N)=0.122$ & \multicolumn{2}{|c|}{$(G)=0.071$} & \multicolumn{2}{|c|}{$(\mathrm{N} \times \mathrm{G})=0.160$} & $(\mathrm{~N})=0.130$ & \multicolumn{2}{|c|}{$(G)=0.068$} & \multicolumn{2}{|c|}{$(\mathrm{N} \times \mathrm{G})=0.164$} \\
\hline
\end{tabular}

The data illustrated in Tables 6 and 7 indicate that, in general, the interaction between nano-chitosan and glutamine acid increased chemical constituents of coriander plant (N, P, K and total carbohydrates percentages as well as total 
chlorophyll content in leaves) as compared with the control. Increased the interacted glutamine acid concentrations from 25, 50, $100 \mathrm{ppm}$ resulted in significant increases in abovementioned characteristics under different levels of nanochitosan rates. In addition, the highest values in this connection were recorded under the effect of interaction treatments between nano-chitosan rate of $(4.0 \mathrm{ml} / \mathrm{l})$ and glutamine acid concentrations at 50 or $100 \mathrm{ppm}$ in first and second seasons, with significant increase compared to control. Chitosan have many special properties regard amine and-OH groups which making it applicable in easily available for chemical reactions. Chitosan is non-toxic material which interacts with poly anions to form complexes and gels [33]. Similar results were reported by [25] on Phaseolus vulgaris plant regarding nano-chitosan effect. In addition, regarding amino acids effect in improving plant nutrients uptake [34] on green bean, El Awadi et al. [35] on snap bean and [36] on mung bean found similar results.

Table 7. Effect on nano-chitosan rate $(\mathrm{N})$, glutamine concentration $(\mathrm{G})$ and their interaction $(\mathrm{N} \times \mathrm{G})$ treatments on total carbohydrates $(\%)$ and total chlorophyll content (SPAD) of coriander (Coriandrum sativum) plant during the two seasons

\begin{tabular}{|c|c|c|c|c|c|c|c|c|c|c|}
\hline \multirow{3}{*}{$\begin{array}{l}\text { Nano-chitosan rate } \\
\qquad(\mathrm{ml} / \mathrm{l})\end{array}$} & \multicolumn{10}{|c|}{ Glutamine concentration (ppm) } \\
\hline & 0.0 & 25 & 50 & 100 & Mean $(\mathrm{N})$ & 0.0 & 25 & 50 & 100 & $\operatorname{Mean}(\mathrm{N})$ \\
\hline & \multicolumn{5}{|c|}{$2018 / 2019$ season } & \multicolumn{5}{|c|}{$2019 / 2020$ season } \\
\hline & \multicolumn{10}{|c|}{ Total carbohydrates $(\%)$ in fruits } \\
\hline 0.0 & 28.57 & 30.19 & 31.10 & 32.19 & 30.51 & 30.26 & 31.74 & 32.92 & 33.34 & 32.07 \\
\hline 2.0 & 29.86 & 33.04 & 33.93 & 34.06 & 32.72 & 30.64 & 32.33 & 34.96 & 35.29 & 33.31 \\
\hline 4.0 & 31.28 & 33.97 & 34.68 & 34.73 & 33.67 & 31.83 & 32.64 & 36.14 & 35.77 & 34.10 \\
\hline Mean $(\mathrm{G})$ & 29.91 & 32.40 & 33.24 & 33.66 & & 30.91 & 32.24 & 34.67 & 34.80 & \\
\hline \multirow[t]{2}{*}{ LSD at $5 \%$} & $(\mathrm{~N})=1.01$ & \multicolumn{2}{|c|}{$(G)=0.56$} & \multicolumn{2}{|c|}{$(\mathrm{N} \times \mathrm{G})=1.30$} & $(N)=0.75$ & \multicolumn{2}{|c|}{$(G)=0.62$} & \multicolumn{2}{|c|}{$(\mathrm{N} \times \mathrm{G})=1.19$} \\
\hline & \multicolumn{10}{|c|}{ Total chlorophyll content in leaves } \\
\hline 0.0 & 29.67 & 29.33 & 31.00 & 30.33 & 30.08 & 30.33 & 30.67 & 33.00 & 31.33 & 31.33 \\
\hline 2.0 & 29.67 & 32.33 & 35.00 & 35.33 & 33.08 & 31.67 & 34.33 & 37.33 & 37.00 & 35.08 \\
\hline 4.0 & 32.67 & 34.67 & 36.67 & 37.67 & 35.42 & 33.67 & 35.67 & 38.67 & 39.00 & 36.75 \\
\hline Mean (G) & 30.67 & 32.11 & 34.22 & 34.44 & & 31.89 & 33.56 & 36.33 & 35.78 & \\
\hline LSD at $5 \%$ & $(\mathrm{~N})=0.97$ & \multicolumn{2}{|c|}{$(G)=0.60$} & \multicolumn{2}{|c|}{$(\mathrm{N} \times \mathrm{G})=1.32$} & $(N)=0.60$ & \multicolumn{2}{|c|}{$(G)=0.74$} & \multicolumn{2}{|c|}{$(\mathrm{N} \times \mathrm{G})=1.26$} \\
\hline
\end{tabular}

\section{Conclusion}

From abovementioned results, it is preferable to spray coriander (Coriandrum sativum, L.) plants with nanochitosan rate at $4.0 \mathrm{ml} / \mathrm{l}$ plus glutamine acid at $50 \mathrm{ppm}$ to enhance the coriander growth, yield components, volatile oil production and chemical constituents of this important aromatic plant.

\section{Reference}

[1] Lawrence, B. M. A planning scheme to evaluate new aromatic plants for the flavor and fragrance industries. In: Janick, J., J. E. Simon. (eds.) New Crops. Wiley, New York; 1993. p.620-627.

[2] Wangenesteen, H., A. B. Samuelesen, K. E. Malterud. Antioxidant activity in extracts from coriander. Food Chemistry. 2004; 88: 293-297.

[3] Jackson, P., N. Jacobsen, A. Baun, R. Birkedal, D. Kühnel, K. Jensen, U. Vogel, H. Wallin. Bioaccumulation and ecotoxicity of carbon nanotubes. Chem. Central J. 2013; 7: 154-175.

[4] Mondal, A., R. Basu, S. Das, P. Nandy. Beneficial role of carbon nanotubes on mustard plant growth: An agricultural prospect. J. Nanopar. Res. 2011; 13: 4519-4528.

[5] Hasaneen, M. N., H. M. M. Abdel-aziz, A. M. Omer. Effect of foliar application of engineered nanomaterials: carbon nanotubes NPK and chitosan nanoparticles NPK fertilizer on the growth of French bean plant. Biochemistry 
and Biotechnology Research. 2016; 4(4): 68-76.

[6] Kowalczyk, K., T. Zielony. Effect of Aminoplant and Asahi on yield and quality of lettuce grown on rockwool. Conf. of biostimulators in modern agriculture. Warsaw, Poland; 2008.

[7] El-Ghamry, A. M., K. M. Abd El-Hai, K. M. Ghoneem. Amino and humic acids promote growth, yield and disease resistance of faba bean cultivated in clayey soil. Australian Journal of Basic and Applied Sciences. 2009; 3(2): 731-739.

[8] Amin, A. A., F. A. E. Gharib, M. El-Awadia, E. S. M. Rashad. Physiological response of onion plants to foliar application of putrescine and glutamine. Scientia Horticulturae. 2011; 129: 353-360.

[9] Marschner, P. Marschner's mineral nutrition of higher plants. 3rd ed. London: Elsevier; 2011. p.672.

[10] Mohamed, E. El-Awadi, Mohamed, S. A. Abd El Wahed. Improvement the growth and quality of green onion (Allium Cepa L.) Plants by some bioregulators in the new reclaimed area at Nobaria Region, Egypt. New York Science Journal. 2012; 5(9):144-120.

[11] Guenther, E. The Essential Oils. New York: D. Von Nostrand Comp; 1961. p.236.

[12] Chapman, D. H., R. F. Pratt. Methods of analysis for soils, plants and waters. Div. Agric. Sci. USA: University of California; 1978. p.16-38.

[13] AOAC. Official Methods of Analysis. 15th ed. Virginia, USA: Association of Official Analytical Chemists, Inc; 1990.

[14] Markwell, J., J. C. Osterman, J. L. Mitchell. Calibration of the Minolta SPAD-502 leaf chlorophyll meter. Photosynthesis Research. 1995; 46: 467-472.

[15] Gomez, N. K., A. A. Gomez. Statical Procedures for Agricultural Research. 2nd ed. New York. USA: John Wiley and Sons; 1984. p.680.

[16] Analytical Software. Analytical Software. Tallahassee, Florida, USA. 2008.

[17] Wanichpongpan, P., K. Suriyachan, S. Chandrkrachang. Effects of chitosan on the growth of gerbera flower plant (Gerbera jamesonii). In: Chitin and chitosan in life science; Uragami T, Kurita K, Fukamizo T. (eds) Yamaguchi, Japan; 2001. p.198-201.

[18] Van, S. N., H. D. Minh, D. N. Anh. Study on chitosan nanoparticles on biophysical characteristics and growth of Robusta coffee in green house. Biocatal. Agric. Biotechnol. 2013; 2(4): 289-294.

[19] Kananont, N., R. Pichyangkura, S. Chanprame, S. Chadchawan, P. Limpanavech. Chitosan specificity for the in vitro seed germination of two dendrobium orchids (asparagales: Orchidaceae). Sci. Hort. 2010; 124(2): 239-247.

[20] Wang, M., Y. Chen, R. Zhang, W. Wang, X. Zhao, Y. Du, H. Yin. Effects of chitosan oligosaccharides on the yield components and production quality of different wheat cultivars (Triticum aestivum L.) in Northwest China. Field Crop Res. 2015; 172: 11-20.

[21] Saavedra, G. M., N. E. Figueroa, L. A. Poblete, S. Cherian, C. R. Figueroa. Effects of preharvest applications of methyl jasmonate and chitosan on postharvest decay, quality and chemical attributes of Fragaria chiloensis fruit. Food Chem. 2016; 190: 448-453.

[22] El-Zohiri, S. S. M., Y. M. Asfour. Effect of some organic compounds on growth and productivity of some potato cultivars. Annals of Agric. Sci. 2009; 47(3): 403-415.

[23] Greenwell, Z. L., J. M. Ruter. Effect of glutamine and arginine on growth of Hibiscus moscheutos "in vitro". Ornamental Hort. 2018; 24(4): 393-399.

[24] Saharan, V., G. Sharma, M. Yadav, M. K. Choudhary, S. S. Sharma, A. Pal. Synthesis and in vitro antifungal efficacy of Cu-chitosan nanoparticles against pathogenic fungi of tomato. Int. J. Biol. Macromol. 2015; 75: $346-453$.

[25] Zayed, M. M., S. H. Elkafafi, A. M. G. Zedan, S. F. M. Dawoud. Effect of nano chitosan on growth, physiological and biochemical parameters of Phaseolus vulgaris under salt stress. J. Plant Production. 2017; 8(5): $577-585$.

[26] Yunsheng, L., A. M. El-Bassiony, Z. F. Fawzy, M. E. El-Awadi. Effect of foliar spray of glutamine on growth, yield and quality of two snap bean varieties. Journal of Agricultural Science and Engineering. 2015; 1(2): 39-45.

[27] Behboudi, F., Z. T. Sarvestani, M. Z. Kassaee, S. A. M. M. Sanavi, A. Sorooshzadeh, S. B. Ahmadi. Evaluation of chitosan nanoparticles effects on yield and yield components of barley (Hordeum vulgare L.) under late season drought stress. J. Water Environ. Nanotechnol. 2018; 3(1): 22-39.

[28] Saeed, M. R., A. M. Kheir, A. A. Al-Sayed. Suppressive effect of some amino acids against Meloidogyne incognita on Soybeans. J. Agric. Sci. Mansoura Univ. 2005; 30(2): 1097-1103.

[29] Dzung, N. A., V. T. P. Khanh, T. T. Dzung. Research on impact of chitosan oligomers on biophysical characteristics, growth, development and drought resistance of coffee. Carbohydr. Polym. 2011; 84(2): 751-755.

[30] Abdel-Aziz, H. M. M., M. N. A. Hasaneen, A. M. Omer. Nano chitosan-NPK fertilizer enhances the growth and productivity of wheat plants grown in sandy soil. Spanish Journal of Agricultural Research. 2016; 14(1): 1-9. 
[31] Okumoto S, G. Pilot. Amino acid export in plants: A missing link in nitrogen cycling. Molecular Plant. 2016; 4: 453-463.

[32] Noroozlo, Y. A., M. K. Souri, M. Delshad. Stimulation effects of foliar applied glycine and glutamine amino acids on lettuce growth. Open Agriculture. 2019; 4: 164-172.

[33] Se, K. K., R. Niranjan. Enzymatic production and biological activities of chitosan oligosaccharides (COS): A Review. Carbohydr. Polym. 2005; 62: 357-368.

[34] Abdel-Mawgoud, A. M. R., A. M. El-Bassiouny, A. Ghoname and S. D. Abou-Hussein. Foliar application of amino acids and micronutrients enhance performance of green bean crop under newly reclaimed land conditions. Australian Journal of Agricultural Research. 2011; 5(6): 459-469.

[35] El-Awadi, M. E., Z. F. El-Bassiony, A. M. Fawzy, M. A. El-Nemr. Response of snap bean (Phaseolus vulgaris L) plants to nitrogen fertilizer and foliar application with methionine and tryptophan. Nature and Science. 2011; 9(5): 87-94.

[36] Razieh, K., M. Tajbakhsh, J. Jalilian. Effect of foliar application of bio-organic fertilizers and urea on yield and yield components characteristics of mung bean. International Journal of Agriculture: Research and Review. 2012; 2(5): 639-645. 